Article

\title{
In Search of Dialogicity: A Comparison of Curricular Documents and Classroom Interactions from Finland and Hong Kong
}

\author{
Sami Lehesvuori ${ }^{1, *}$, Kennedy Kam Ho Chan ${ }^{2}$, Umesh Ramnarain ${ }^{3}$ and Jouni Viiri ${ }^{1}$ \\ 1 Department of Teacher Education, University of Jyväskylä, P.O. Box 35, 40014 Jyväskylä, Finland; \\ jouni.viiri@jyu.fi \\ 2 Faculty of Education, University of Hong Kong, Pok Fu Lam, Hong Kong; kennedyckh@hku.hk \\ 3 Department of Science and Technology Education, University of Johannesburg, P.O. Box 524, Auckland Park, \\ South Africa; uramnarain@uj.ac.za \\ * Correspondence: sami.lehesvuori@jyu.fi; Tel.: +358-40-8054-952
}

Received: 10 August 2017; Accepted: 18 September 2017; Published: 25 September 2017

\begin{abstract}
The prevailing consensus is that science teaching should be more student-centered and guide learners towards more phenomenon-based and authentic problem-solving activities. This approach is reflected in educational policies and recently reformed curricula. However, there is limited research on how these frameworks actually manifest in curricula and how to facilitate student-centered pedagogy. In this study, we examine the student-centered features of the curricula of two countries: Finland and Hong Kong. Student-centeredness in the classroom can be assessed using the principles of dialogicity. Dialogic principles underpin student-centeredness, particularly in teacher-orchestrated whole-class discussions. Dialogic interactions include mutual consideration of different and even diverging views. This study first reviews the dialogic themes in the curricula, then explores the ways in which student-centered approaches can be realized in practice by analyzing the dialogic interactions in two classroom examples. The dialogic themes identified in the curricula are considered in the context of the classroom examples. As science classroom interactions are still prevailingly teacher-centered and authoritative, the insights into alternative approaches generated by the examples are discussed. This study prepares the context for further discussion of curricular development, dialogicity and its implications for teaching and teacher education.
\end{abstract}

Keywords: curricular reform; dialogicity; science teaching; student-centeredness

\section{Introduction}

"As a subject, health education is pupil-oriented and supports functionality and involvement. The starting point for the instruction must be the child or young person's daily living, growth, and development, and of course the human life span." [1] (p. 196)

This sentence raises some questions relevant to this study: what subject is not pupil-oriented (Note: If directly translated from Finnish, student-centered would be a synonym) or student-centered? Which subjects are not concerned with daily life? For example, are scientific subjects not essential over the human lifespan? Thus, is it not crucial for scientific subjects, such as physics, to also proceed from students' everyday experiences towards more scientific explanations? In this study, we examine whether student-centeredness is truly present in school science curricula, particularly physics curricula. This is demonstrated through the application of the principles of dialogicity, which we consider capturing and explicating some of the essential features of student-centeredness.

Around the world, curricula are being reformed by more student-centered approaches to teaching and learning [2,3]. Student-centeredness is understood as giving students active roles in classrooms and 
responsibility for their own learning. In science, this can be described as having the student do science rather than recreating science [4]. In this study of student-centeredness, the focus is on classroom interactions that allow student voices to be part of scientific meaning making. The aforementioned curricular reforms align with scholarly trends, which draw on sociocultural perspectives emphasising the role of verbal communication in learning $[5,6]$. When addressing this co-construction, the focus is on exploring how the mutual acknowledgement of different voices, including student voices, can enrich teaching and learning. This acknowledgment is at the heart of dialogicity [7] followed by many researchers in education field [8-11].

Student-centeredness has reached the forefront of educational policy at the same time as it is becoming increasingly challenging to maintain students' interest and motivation, especially in learning scientific subjects [12]. Evidence shows that a more student-centered approach in teacher-orchestrated discussions can lead to increased student motivation and engagement [13]. In contrast, teacher-centered approaches, complemented by memorisation of fragmented knowledge, do not meet today's requirements: the surrounding world is rapidly changing, foregrounding the need for phenomenal and intersubject understanding of larger entities connected to everyday life [2]. Although curriculum documents address policies, expected goals, objectives and preferable pedagogies [14] and provide a lens through which educational actions can be evaluated [15], how curricula could link to pedagogy in classrooms and teacher orientations is rarely reported [16].

As Voogt and Roblin [17] state, if the levels of the intended, implemented and attained curriculum are not in balance, change is unlikely to occur. In this study, by drawing on key themes identified from curricula reform in Finland and Hong Kong, we identify explicit examples of student-centeredness, which are identified using features of dialogicity $[10,18]$. Alexander's framework is well-known worldwide when interpreting classroom pedagogy [19-21], yet the methodological applicability of Alexander's principles has been addressed in a limited manner [19]. Our aim is to apply Alexander's principles to analyze curricular documents and to illustrate these theoretical concepts of dialogic teaching/principles with examples of real classrooms.

\subsection{Background and Rationale for the Study}

The rationale for the study is related to the following question: why is it worthwhile to study the link between curricula and implementation? The answer is simple: without curricula, there would be no meaningful plan for implementation, and without implementation, curricula would have little if any meaning [22,23]. Following Howell and Evans [23], this study emphasizes the learning process rather than goals or summative assessments [22]. We are not seeking for causal link or effect of curricula on classroom interaction in this study. Instead, we provide two examples how themes found in curricula could manifest as dialogic practice in science classrooms, a form of interaction still infrequently found in science classrooms [20].

\subsubsection{The development of curricula in Finland and Hong Kong}

The Finnish National Core Curriculum was recently renewed [1] and is currently being implemented for the first time (2016-2017). The core curriculum framework is a national framework complemented by local curricula that are finalized by municipalities. The guidelines for the new curriculum framework highlight the following key aspects.

- The student is an active participant.

- Learning together stimulates students' creative and critical thinking and problem-solving skills and their ability to understand different points of view.

- Student-centeredness involves doing things alone and together, as well as the thinking, planning, investigating and versatile assessment of these processes.

Quick interpretations reveal features of this curriculum that pertain to student-centeredness. 
- Student-centered learning puts students' interests first and acknowledges that student ideas are central to the learning experience.

- In a student-centered classroom, students choose what they will learn, how they will learn it and how they will assess their own learning [24].

The new Finnish curriculum also emphasizes the use of inquiry-based approaches as part of phenomenon-based learning. The use of inquiry-based approaches was also a recurring theme in the previous Finnish curriculum [1], which remained partially implemented in the autumn 2016 semester and was finally completely replaced by the new curriculum in 2017. Parties not involved in the curriculum's creation may find it difficult to conceptualize and thus implement the different layers of the curriculum [25]. This issue has been thoroughly considered by the people preparing the renewed Finnish National Core Curriculum, and is the reason local municipalities and teachers have been given the responsibility of finalizing the local curricula.

In Hong Kong, the junior science curriculum is now undergoing a minor revision and a provisional draft for the new curriculum is available online [26]. This new curriculum supplements the Science Education KLA (Key Learning Area) Curriculum Guide, which is used for both primary and secondary levels. The new document provides only the rationale, aims and learning targets of the curriculum and the curriculum framework. The teaching strategies and assessment strategies are now under revision. This updated curriculum is similar to the current curriculum, which was first implemented in 1998. The new updates highlight some recent trends in science education such as STEM education and language across the curriculum. The major goal is unchanged, which is to develop 'the necessary scientific and technological knowledge and skills to live and work in the 21st century' in the lives of students ([26] (p. 1); [27] (p. 2)). Compared with the pre-1998 curriculum, there has been a significant reduction in science content in both the current and new curricula. It is noteworthy that in both curricula teachers are expected to use investigative approaches in their science lessons, and that students are expected to be involved in 'defining problems, designing experiments to find solutions, carrying out practical work and interpreting the results' [27] (p. 4). It is believed that students will learn science content, inquiry practices and the nature of science through their engagement in scientific investigations. Although the sections on teaching and assessment strategies are still under revision, it is believed the recommended strategies in the new curriculum will be similar to those in the current curriculum. In terms of teaching strategies, teachers are encouraged to use 'student-centered and interactive approaches' that can stimulate higher-level thinking in students [27] (p. 15). Assessments should also be designed in a way that requires students 'to think and work actively' [27] (p. 129). In sum, the pre-1998 content-focused science curriculum has been transformed into one that puts less emphasis on canonical science content and more emphasis on developing students' scientific skills (e.g., learning scientific methods and problem-solving skills) and generic skills (e.g., communication skills).

Looking across the changes in the curricula, several trends can readily be identified. First, the curricula goals seem to have expanded from the mere transmission of scientific content to the development of scientific skills/inquiry practices to prepare students for their future needs. Second, the active role of students has been emphasized: students are expected to participate actively in the learning process. Third, the traditional transmission mode of teaching is being discouraged, and an inquiry-based approach is being advocated. These general trends mirror the global trends in science education.

\subsubsection{Theoretical Background to Student-Centeredness and Dialogicity}

It is interesting to note that whilst inquiry-based approaches tend to overlook the dialogic aspect of science teaching and learning [28], the main idea of inquiry as engagement-, problemand evidence-based activity [29] (p. 25), in many ways, is related to the fundamental ideas of dialogic teaching [30]. The depth of understanding offered by dialogic and communicative approaches concerning the complex interactions of science teaching and learning complements an inquiry-based approach. Furthermore, including dialogicity in science education addresses concerns about the lack of 
openness in inquiry-based approaches. This means that learners are working towards predetermined outcomes, as if they were following a prescribed recipe [31].

The quest for dialogicity in this study draws on two scholarly descriptions: those of Alexander [18] and Mortimer and Scott [10]. Alexander's [18] principles for dialogic teaching are as follows:

- Collective: the teacher and pupils jointly participate in learning as a group or as a class.

- Reciprocal: teacher and pupils listen to each other, share ideas and consider alternative views.

- Supportive: pupils can present their ideas freely without fear of being incorrect.

- Cumulative: the teacher and pupils develop their ideas together, jointly constructing knowledge.

- Purposeful: the teacher plans and guides the discourse, paying attention to educational goals while paying attention to the preceding principles.

Alexander [18] sees dialogic teaching as applicable to the whole teaching process; in this view, classroom dialogue builds on previous contributions and is aimed in a specific direction. In contrast, Mortimer and Scott [10] make a clearer distinction between authoritative and dialogic approaches in the science classroom. This aligns with Bakhtin's [6] idea of giving space to different voices and ideas. Although science teaching cannot be considered solely dialogic, mutual appreciation of everyday ideas should be present for example when opening up problems [32].

The framework for Mortimer and Scott's [10] communicative approach differentiates the typical transmission modes of teaching from modern classroom interactions in which students are given the freedom to, for example, describe, compare, classify and argue while taking part in discussions. Their framework for describing classroom discourse consists of four categories combined in two dimensions: interactive/non-interactive and authoritative/dialogic. Interactive talk allows students to participate, whereas non-interactive talk is a type of lecture. The dialogic approach takes account of diverging ideas, whereas the authoritative approach focuses on a specific point of view, usually the scientific view, controlled by the teacher:

- In the question-answer routine of the authoritative and interactive approach, students' responses are often evaluated and the teacher neglects diverging ideas. The authoritative approach focuses on the scientific point of view.

- In contrast, the dialogic and interactive approach explores and exploits students' ideas (e.g., everyday views) and has no evaluative aspect. The dialogic approach is considered when the teacher is not trying to assert a specific point of view. Rather, the teacher works with contrasting views.

- In the authoritative and noninteractive approach, the teacher presents scientific content through lectures and takes no account of contrasting points of view.

- In the dialogic and noninteractive approach, the teacher works with contrasting points of view, such as students' everyday views, and moves on to present the scientific view. Thus, although the teacher is lecturing, divergent ideas are being discussed.

In summary, teachers can adopt communicative approaches that acknowledge different voices and ideas (in this way adhering closely to the core characteristics of dialogic teaching), or they can lean more authoritatively towards the scientific point of view to steer learning in the desired direction. In both cases, the teacher will ideally nurture sociocultural principles and the essential role of language in learning. In the Mortimer and Scott [10] framework, in violation of Alexander's [18] principles, the dialogic approach is seen as having its own space in classroom discussions, within which different, authentic and even inchoate ideas may emerge. These can be addressed more authoritatively only at a later stage.

Accordingly, it can be understood that meaningful science teaching requires the teacher to create space for different views and then to be able to use these different views when subsequently moving towards scientific conclusions via a more authoritative approach [32]. Reflecting on the preceding notions, it is apparent that dialogic and dialectic (authoritative) processes can both be present in 
meaningful science classroom interactions [33]. This dualism is implicitly present in fundamental principles of education. As described by Wahlström [34].

The mission of education is to introduce specialized and abstract knowledge to the students, but it is also to make them reflect on this knowledge, and to elucidate different opinions of the consequences of the knowledge of nature and social life and its connections. Hence, forming an opinion, reflecting, or analysing, is not a private capacity but a common activity, which brings new knowledge into the classroom alongside with that formulated in a textbook, and it is the students, together with the teacher, who are the partakers in such a genuine discussion — not aiming at reaching consensus but at elucidating differences. [34] (pp. 437-438)

This quotation suggests that school is not about transferring a common knowledge; rather, it is about understanding, for example, the differences between everyday and scientific views and being able to communicate these differences together. It is not only the voice of the teacher that conveys the scientific 'truth' in classrooms; students' ideas, which echo the everyday experiences and ideas of their social situations, are just as truthful [20] (p. 19). Dialogicity has been explicitly acknowledged in educational policy in the United Kingdom [20].

Although the different theoretical grounds and rivalry between Alexander [18] and Mortimer and Scott's [10] descriptions of dialogicity have been pointed out, the focus is not on their differences, but rather on identifying how these two approaches have been adopted and adapted in the real dialogic classroom interaction examples.

\subsubsection{Action Indicators for Dialogicity}

A typical form of science teaching is an interaction initiated by the teacher, followed by a student response, followed by teacher feedback [35]. This three-turn pattern of talk is also known as the IRF pattern of discourse, where ' $I$ ' stands for the 'initiation by the teacher' (such as a question), ' $R$ ' for the 'response by the student' and ' $\mathrm{F}$ ' for the 'feedback (or follow-up in more general descriptions) by the teacher' [36]. In addition to the nature of questions [37], the nature of teacher feedback (F) is considered an essential element in activating student thinking and reasoning, particularly when feedback extends beyond evaluation [38].

A more recent derivation and extension of the triadic talk pattern is the IRFRF (This is congruent with the IRPRP pattern (in which P stands for prompt) originally introduced by Scott, Mortimer and Aguiar [39] chain in which student responses are followed by the teacher directing the turn back to the learners without an evaluation. For instance, the teacher may elicit students' points of view and then prompt the students' further thinking instead of evaluating their responses [39]. Chain-formed patterns have the potential to engage students in more interactive teacher-student interactions, especially through supportive feedback [40]. Thus, chain patterns often hold the promise of promoting a dialogic approach especially through supportivity.

Limited studies address how curricular guidelines are implemented in practice, few have addressed whether dialogic principles exist in curricula and how they could actually manifest in real classrooms [20]. Alexander's [18] descriptions are seminally adapted to the more microscale analysis and interpretations appropriate for foregrounding the link between themes in curricula and real examples. As Mortimer and Scott's [10] framework has proved its strengths in finding and interpreting dialogic interactions, especially in science classrooms, it complements the methodology.

\subsection{Purpose of the Study}

The following objectives are addressed:

- Detecting and pointing out dialogic themes in the school science curricula of Finland and Hong Kong; and 
- Illustrating classroom examples of dialogic teaching in relation to the themes identified in curricula.

The first research aim sheds light on whether student-centeredness, and especially dialogicity is present in science curricula of Finland and Hong Kong. Despite a general impression of curricular documents focusing on content and context, we hypothesize that pedagogy is taking place through the current reforms. In this study, this is addressed with focus on dialogicity. Within the second research aim, this study provides further insights into explicit ways for using dialogicity to present and convey student-centeredness. We show that dialogicity is possible in science classrooms and in different cultures despite challenges acknowledged with dialogic implementation [41,42]. However, we cannot build causal link between curricula and practice here, yet the insights explored are used to discussion on this matter so that dialogicity would become more everyday than infrequent.

\section{Methods}

\subsection{Context}

The selected curricular documents refer to the same age groups and subject (i.e., physics). However, the teacher and video examples illustrate specific features of dialogicity, and were selected to reflect the thematic analysis of the curricular documents and related discussions.

The initial video analysis and identification of dialogic examples in Finland was based on the communicative approach framework presented previously [10]. After an initial analysis, only a few possible dialogic episodes were found and therefore used as the action examples. The examples from Hong Kong have been reported elsewhere [43], as an example of a reform-advocate teacher who encourages pupils to talk. One episode from this teacher's class was selected as a dialogic example. Thus, this study considers one case from each country to demonstrate how student-centeredness and dialogicity [18] could take place even in the prevailingly authoritative context of school science. Although we acknowledge that dialogicity is extremely infrequent, the examples show that it still is possible in real classroom settings.

\subsection{Data Collection and Analysis}

Curricular documents and chapters were selected based on the following criteria: they were from the physics curricula for ages $12-15$, thus context and content was also known by the authors. The classroom interaction examples discussed in this study were drawn from the data of several projects investigating different forms of classroom interaction. The overview of the initial data set as well as resources for the curricular material can be found in Appendix A.

\subsubsection{Curriculum mapping: Thematic Analysis of the Curricula}

We adapt an approach from Lavrenteva and Orland-Barak [44] (originally modified from the framework introduced by Ben-Perez [45]) to classify the themes. The major themes are divided theoretically into student- and teacher-based dimensions.

The teacher-based theme is further divided into pedagogical and instructional dimensions, according to the following subcategories.

- The term pedagogical here refers to classroom actions and approaches that teachers implement during teaching. Pedagogical approaches may take place inside the instructional setting (e.g., acknowledging students' prior/everyday views within inquiry-based learning).

- The term instructional here refers to educational models, predesigned settings or educational strategies through which teaching and learning takes place (e.g., inquiry- or phenomenon-based learning, scientific argumentation, scientific modelling). 
More generally, instructional strategies are used to cover the various aspects of sequencing and organising content, specifying learning activities and deciding how to deliver content and activities [46].

Although the focus in the interaction examples is on teacher-orchestrated interactions, the student dimension is used to validate the thematic approach and to see how both dimensions emerge from the curricular data. The framework we use for the student dimension in dialogicity is primarily based on Mercer's [47] descriptions of cumulative and exploratory talk, which are briefly described in Table 1 (As disputative talk, in which students neglect diverging and competing views, does not fundamentally resonate with dialogicity, it is not included.). The description of exploratory talk coincides with the idea of purposefulness: in addition to considering different points of view, students should be critical and constructive during collaborative activities.

Table 1. Theory-derived themes used in the analysis of the curricular documents.

\begin{tabular}{|c|}
\hline Themes for dialogicity \\
\hline $\begin{array}{l}\text { Collectivity: Teacher should enhance instructional and pedagogical activities that foster collectivity, e.g., teacher-orchestrated } \\
\text { discussions [18] (Theme Aa/b1). } \\
\text { A = Teacher-based dimension; } \mathrm{a}=\text { pedagogical; } \mathrm{b}=\text { instructional }\end{array}$ \\
\hline $\begin{array}{l}\text { Reciprocality: Teacher and students should listen to each other during discussions, share ideas and consider alternative } \\
\text { views }[10,18] \text { (Theme Aa/b2). }\end{array}$ \\
\hline $\begin{array}{l}\text { Supportivity: Teacher should support and prompt students further in their thinking. Students should not fear being wrong; } \\
\text { instead, all ideas are welcomed [10] (Theme Aa/b3). }\end{array}$ \\
\hline Cumulativity: Teacher should consider students' points of view when foregrounding scientific explanations [9] (Theme Aa/b4). \\
\hline $\begin{array}{l}\text { Purposeful: Teacher should plan and guide activities while paying attention to scientific processes and strategies with the explicit } \\
\text { presence of educational goals [18] (Theme Aa/b5). }\end{array}$ \\
\hline $\begin{array}{l}\text { Collectivity: Student should engage in problems collectively and communicate with peers, e.g., during authentic inquiry or other } \\
\text { instructionally organized settings [18] (Theme B1). } \\
\text { B = Student-based dimension }\end{array}$ \\
\hline Reciprocality: Students should listen to each other without disputation [47] (Theme B2). \\
\hline $\begin{array}{l}\text { Supportivity: Students should listen to each other respectfully. Different ideas are welcomed and encouraged by others without } \\
\text { disputation [47] (Theme B3). }\end{array}$ \\
\hline $\begin{array}{l}\text { Cumulativity: Students should build on what has been said and think about how inquiries have helped to clarify the knowledge } \\
\text { (note: without criticality, this process does not meet the requirements for exploratory talk as described in [47]) (Theme B4). }\end{array}$ \\
\hline $\begin{array}{l}\text { Purposeful: Students should meaningfully engage in problems and phenomena and also pay attention to argumentative strategies } \\
\text { (cf. Mercer's exploratory talk) and methods instead of making hands-on inquiries step by step. Students should implement } \\
\text { versatile assessments during the process (Theme B5). }\end{array}$ \\
\hline
\end{tabular}

In summary, the themes originate from recent descriptions of student-centeredness [2] and from descriptions of dialogicity [10,18]. Although the identified themes are mainly based on Alexander's [18] definitions, the specific nature of science classrooms require the complementary use of Mortimer and Scott's [10] descriptions of dialogicity (see supportivity and cumulativity) The development of themes, therefore, is more data-based than grounded (An example of a grounded thematic approach can be found in Voogt and Roblin's [17] comparative study. Curriculum mapping was conducted with Atlas.ti data analysis software, which is widely used in qualitative studies.

\subsubsection{Classroom Reality-Exploring Student-Centeredness in Whole-Class Teaching}

Following Alexander [18], we acknowledge that all of these dialogic features should be present and interwoven into all classroom interactions. Some studies have addressed the explicit difference between dialogic principles [19], yet further explication is needed. To address this gap, we highlight only one principle characteristic for each case.

The selection procedure. In this study, the initial selection of the cases requires identifying dialogic episodes in the video dataset. Each episode consists of an entity consisting of an activity, topic or communicative approach [21]. Two dialogic episodes, one from each country, were confirmed through 
a triangulation process among the researchers. The process for identifying a dialogic episode is discussed in detail in the findings section.

The analysis. Although the communicative approach has been useful in categorising classroom interactions, it is not sufficient for categorising curricular descriptions. This study analyzes the selected dialogic examples using dialogic indicators $[19,48]$ derived from Alexander's dialogic teaching framework, presented in Table 1, to understand how the curricula are manifested in the classroom. Our interpretations of the classroom interactions follow the general principles of sociocultural discourse analysis [6]. This approach is less focused on language itself and more focused on the functions language serves in joint activities.

Trustworthiness. To ensure the validity of the findings, the authors triangulated their research throughout the study process [49]. The interpretations of the case examples were first individually interpreted by the first and second authors and then evaluated by the third and fourth author. Differences were discussed among all of the authors until a consensus was established.

\section{Findings}

\subsection{Curriculum Mapping: Thematic Analysis of the Curricula}

The thematic analysis is presented in Table 2. An example is provided for each dialogic theme from each country when a theme is found and coded. The frequency of the occurrences is presented after each example.

Comments: The results of the thematic analysis reveal that some features of dialogicity are present in the curricula of Hong Kong and Finland.

Regarding the specific features of dialogicity [18], interestingly, one clear reference for supportivity is found in the renewed Finnish curriculum [2]: "The work process is guided through constructive feedback and questions. Supporting feedback fosters especially the development of inquiry skills and building of motivation" (Translated from [2] (p. 391)). This is the only, yet clear, reference to supportivity: teachers should enhance student learning through feedback. Thus, the renewed curricula can be said to address student-centeredness. In addition, new features include an emphasis on individual learning and the use of ICT in physics inquiries.

Cumulativity can be considered the unifying point between the previous curricula of Hong Kong and Finland. Both the teacher- and student-centered dimensions acknowledge that learning should build on students' previous knowledge and experiences. However, cumulativity is missing from the renewed curricula of Finland and Hong Kong. In the case of Hong Kong's supplementary curriculum, there are fewer references to dialogic features in the new curriculum, as the chapter 'Notes on teaching strategies' [27] (p. 15) is not included in the supplement. As mentioned previously, the older version is still valid for those parts not renewed.

What is distinctly present in the Hong Kong curricula is purposefulness in both teacher and student dimensions: 'teachers should choose appropriate teaching methods' [27] (p. 15); 'students should ... choose an appropriate means of communication to suit the purpose' [27] (p. 17). In relation to purposefulness, a specific feature of the Hong Kong curricula is encouraging teachers to use scientific argumentation, which can be considered a pedagogical approach that addresses both the epistemic and content strands of science teaching and learning [50]. One distinct description underpinning this view can be found in the earlier curriculum [27]: "The discussion of effects of radio waves on health introduces the idea that scientists may disagree among themselves due to their different interpretation of facts. Students should distinguish between claims and arguments that are based on scientific considerations and those that are not" [27] (p. 120). This explicit reference to the fundamentals of scientific argumentation is unique in the data explored for this study. 
Table 2. Themes and examples of curricula.

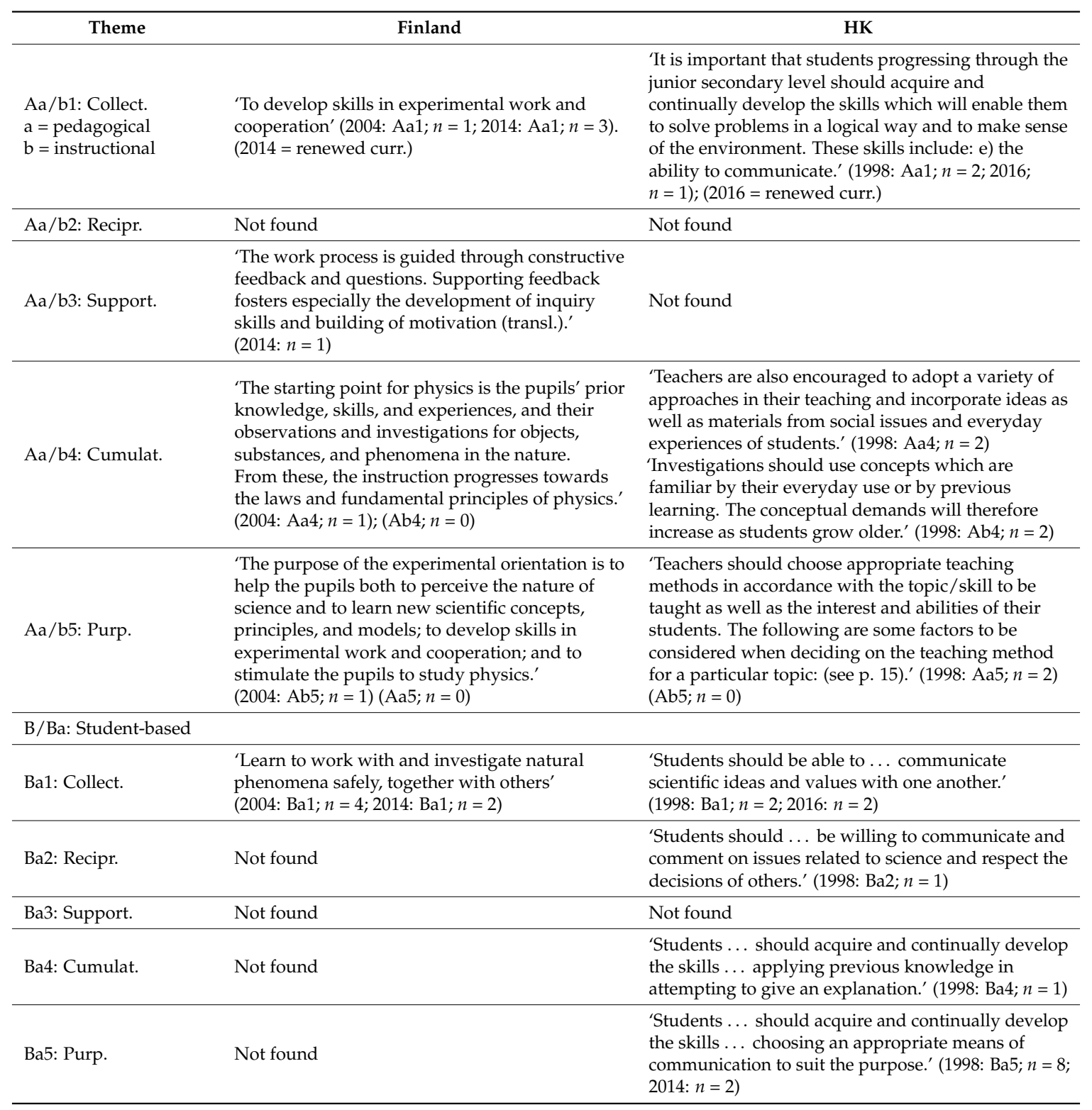

\subsection{Examples of Dialogic Interactions in Science Classrooms}

\subsubsection{Example 1: Finland—Fostering Cumulativity}

The topic of the Finnish example (Table 3) is electricity, specifically electrical power. This episode begins as the students stop their group work and the teacher recaps the first steps of the experiment and begins to inquire about the students' observations.

Table 3. Finland example.

\begin{tabular}{ccl}
\hline Turn & Participant & Transcript \\
\hline 1 & Teacher: & Okay! Let's see. We switched the current on. \\
\hline 2 & Students: & Yes! [many students] \\
\hline 3 & Teacher: & Well then. What was the effect when we increased the voltage? \\
\hline 4 & Student 1: & The engine went faster. \\
\hline
\end{tabular}


Table 3. Cont.

\begin{tabular}{|c|c|c|}
\hline Turn & Participant & Transcript \\
\hline 5 & Teacher: & All right [not evaluative]. Anything else? \\
\hline 6 & Student 2: & [Inaudible.] \\
\hline 7 & Teacher: & $\begin{array}{l}\text { All right [not evaluative]. Well then ... let's continue. You were supposed to obstruct } \\
\text { [brake] the engine ... What happened? }\end{array}$ \\
\hline 8 & Student 3: & The light got brighter. \\
\hline 9 & Teacher: & $\begin{array}{l}\text { Okay [not evaluating]. What does it mean then when the light bulb shines brighter in } \\
\text { the electric circuit? What has changed? }\end{array}$ \\
\hline 10 & Student 4: & We're feeding more current into it? \\
\hline 11 & Teacher: & But what about the engine? More current? Did the engine go faster? \\
\hline 12 & Student 4: & No. \\
\hline 13 & Teacher: & But you obstructed it. \\
\hline 14 & Student 4: & Well, it is sort of ... the energy or current sort of goes here. \\
\hline 15 & Teacher: & Hmmm [nodding and waiting for elaboration]. \\
\hline 16 & Student 4: & Well the current got stuck at the light bulb because it couldn't go here. \\
\hline 17 & Student 5: & $\begin{array}{l}\text { A blockage formed here, and the current couldn't get through, so it stayed there ... } \\
\text { [Students } 4 \text { and } 5 \text { laughing] It went to the light bulb. }\end{array}$ \\
\hline 18 & Teacher: & $\begin{array}{l}\text { Mmm, some great stories you've come up with there. OK, so, we dropped the } \\
\text { revolutions [obstructed engine] ... the light bulb shone brighter and the current } \\
\text { increased. Now, when we think about this whole lot in terms of power ... when do } \\
\text { you think the engine was most powerful? You first had an opportunity to adjust the } \\
\text { voltage [ } \mathrm{s} \text { wait time]. Did it have an effect on the ... power? }\end{array}$ \\
\hline 19 & Student 6: & Yes. \\
\hline 20 & Teacher: & How? Did the power increase or decrease when you increased the voltage? \\
\hline 21 & Student 6: & It increased. \\
\hline 22 & Teacher: & And the engine went then? [Narrowed prompt.] \\
\hline 23 & Student 6: & Faster. \\
\hline 24 & Teacher: & $\begin{array}{l}\text { Okay then [not evaluative]. Well, what about then when we obstructed the engine. } \\
\text { The light bulb got brighter. Was the power more or less then? ... Well, let's see, let's } \\
\text { see ... [Teacher leaves interaction chain open and moves on to the next episode of } \\
\text { teacher demonstration, during which the teacher reviews some of the student ideas.] }\end{array}$ \\
\hline
\end{tabular}

Confirming the dialogic and interactive approach. We begin our interpretation by drawing specifically on the teacher's follow-up moves as central indicators of a dialogic/interactive approach. In this episode, the teacher does not evaluate the student responses (e.g., turns 5, 7 and 9). Instead, he asks for alternative observations (turn 5) and further explanations (turns 9 and 11), prompting the students further. More generally, these turns are considered prompts to initiate more thoughts or encourage others to participate. In turns 16 and 17, the teacher also gives the students the opportunity to formulate and freely express their responses without interruption and allows an exceptionally long wait time in turn 18. Within turns 16 and 17, the student responses reveal typical misconceptions about the nature of electric current. The teacher seems to consider it important to not correct these responses at this point. Instead, the teacher expresses appreciation for the students' explanations and moves on to the concept of power (turn 18). All in all, this episode is an example of an 'idea-sharing' [51] (p. 75) discussion in which the teacher validates students' responses through recognition rather than evaluative feedback. This episode can be considered as dialogic because it meets the following criterion:

- The presence of dialogic indicators, such as prompting for further explanations and providing neutral feedback constitute a dialogic and interactive episode.

Indicators for cumulativity. The teacher closes down the discussion in turn 24 and moves on to the next episode in which the teacher demonstrates, for example, what happens to the current when the 
electric drill is obstructed. In this way, the teacher clarifies the misconception previously revealed by students 4 and 5. Based on our analytical framework, it can be argued that this episode includes the cumulative consideration of ideas. The teacher is not merely collecting student responses; instead, he builds on what has been done and said (e.g., 'OK. What does it mean then when ... ?') and leaves the discussion open, but ready for closure in the following authoritative episode (e.g., 'well, let's see ... ').

Based on the preceding discussion, the episode can be considered to have cumulativity (see Theme A4 in Table 1) according to the following indicators:

- Supportive consideration of pre-experiences gradually narrows towards more scientific definitions (turn 18) of electrical power, signalled by the teacher-directed initiation and prompts finally closing the interactive episode; and

- Not only are pre-experiences collected during the dialogic episode, they also provide the foundation of the forthcoming episode in which the teacher more authoritatively weighs the observations during the teacher demonstration.

\subsubsection{Example 2: Hong Kong-Balancing Dialogicity and Purposefulness}

This is a Form 1 (Grade 7) integrated science lesson. The original lesson is the first half of a double lesson. The example (Table 4) episode begins with the teacher responding to a student's wonderment question about the amount of salt to be used in the experimental inquiry: 'How much salt do we add to make the egg float?'

Table 4. Hong Kong example.

\begin{tabular}{|c|c|c|}
\hline Turn & Participant & Transcript \\
\hline \multirow[t]{3}{*}{1} & Teacher: & $\begin{array}{l}\text { Oh, yes. We don't directly use salt water because we want to know in detail how many spoonfuls of } \\
\text { salt we add to make the egg float. OK? }\end{array}$ \\
\hline & & Good, any questions for this experiment? \\
\hline & & $\begin{array}{l}\text { I would like to ask. In the natural environment, do we have any phenomenon that relates to this } \\
\text { experiment? Ah... Hung Chan. }\end{array}$ \\
\hline 4 & Student 1: & The Dead Sea. \\
\hline 5 & Teacher: & Mmm, you think of the Dead Sea. What is the characteristic of the Dead Sea? \\
\hline 6 & Student 1: & Much salt ... \\
\hline 7 & Teacher: & Then? I know it's salty. \\
\hline 8 & Student 1: & It allows things to float. \\
\hline 9 & Teacher: & It allows things to float. But there are many things floating in our Victoria Harbour. \\
\hline 10 & Student 1: & There is no living thing in the sea... \\
\hline 11 & Teacher: & $\begin{array}{l}\text { Oh, it's too salty so that there are no fish, no living things in the sea. How about it making things } \\
\text { float? }\end{array}$ \\
\hline 12 & Student 1: & It can make a man float. \\
\hline \multirow[t]{2}{*}{13} & Teacher: & Even a man can float. Thank you, Hung Chan. \\
\hline & & $\begin{array}{l}\text { What Hung Chan said is that the power of floating of the Dead Sea is greater than Victoria Harbour's. } \\
\text { I won't drown even if I don't know how to swim? Is that right? Why? Why in the Dead Sea ... the } \\
\text { power of floating is so great? }\end{array}$ \\
\hline 15 & Student 2: & Salt, much salt. \\
\hline \multirow[t]{2}{*}{16} & Teacher: & $\begin{array}{l}\text { Oh, because more salt is added, the greater the power of floating. In other words, if you add a little } \\
\text { salt in the experiment, the egg may not float. If you add more, the egg may float. Is that right? }\end{array}$ \\
\hline & & Can sugar make it [float]? There is the Dead Sea, how about a sugar sea? Can sugar make it? Can't it? \\
\hline 18 & Student 3: & Don't know ... \\
\hline \multirow[t]{4}{*}{19} & Teacher: & Raise your hand if you say yes. [Two to three students raise hands.] \\
\hline & & Raise your hand if you say no. [More students raise hands.] \\
\hline & & Who wants to try? Listen, today the class is split into two groups. \\
\hline & & $\begin{array}{l}\text { Listen, each group has a set of instruments, including a bottle of salt, a bottle of sugar, OK? Good. } \\
\text { Mmm, groups } 1,3,7 \text {, try salt, OK? Groups } 2,4,6,8 \text {, try sugar, OK? }\end{array}$ \\
\hline
\end{tabular}


Confirming the dialogic and interactive approach. After responding to a student question in turn 1, the teacher opens up space for a discussion of everyday contexts. Although the question is open, the Dead Sea example is expected. This answer, however, sets the ground for the following discussion during which the teacher, through counter-argumentation [50] in turn 9, pushes students to think a bit more deeply.

In turn 16, the teacher steers the discussion towards closing down the whole-class discussion and raises the question of whether sugar can make things float (i.e.,' $\ldots$ how about a sugar sea?'). The teacher splits students into groups that agree or disagree with the hypothesis. This is a typical approach for establishing argumentation based on observations and data gathered during inquiries. Even if it is not explicit, this episode can be considered dialogic and interactive due to the following actions:

- The teacher prompts students to offer views about everyday phenomena before shifting the focus towards the inquiry;

- The teacher encourages students to share their ideas and provides supportive feedback (turn 13) after challenging student(s) through counter-argumentation; and

- Throughout, the teacher explicitly refers to student 1 's explanation when reviewing the Dead Sea example. (Turn 13; This is congruent with the dialogic and noninteractive approach on a microscale.)

Indicators for purposefulness. This episode links the previous (assignment of inquiries) and forthcoming (inquiry-phase) episodes meaningfully together. The teacher opens up the floor for student inquiry, adopting the structure of an Argument-Driven-Inquiry (ADI) [52] and dialogic inquiry-based learning [42]. The common point for both approaches is that pre-existing ideas are considered before the actual inquiry phase.

For the following reasons, we consider this episode to incorporate purposefulness (see Theme A5 in Table 1).

- Although it is raised by a student, the everyday example of the Dead Sea is probably a pre-planned example to set the stage for more open discussions.

- The teacher shows awareness of students' misconceptions about buoyancy and density and uses students' conceptions to probe the ideas further. This is signalled through provocative follow-ups (Turns 7 and 9).

- The teacher ends the discussion with a question (Turn 16: 'Can sugar make it?') to set the ground for the actual inquiry phase.

- Thus, this episode is purposefully linked to the assignment of the inquiry and the actual inquiry phase, displaying both instructional and pedagogical strategies for argumentation [53] and dialogic inquiry [42].

\section{Discussion}

The first aim of this study is to explore how student-centeredness is featured in the science curricula of the two case study countries. First, we use the established principles of student-centeredness and dialogicity to derive themes common to student-centered approaches. These themes are used to analyze the science curricular documents of Finland and Hong Kong. Then, drawing particularly on definitions of dialogicity, we identify examples of real classroom student-centered interactions. Thematic analysis of the curricula reveal features of student-centeredness, yet dialogicity is only present in the curricula of Finland and Hong Kong. Although the infrequency, and even absence of dialogicity, might be expected, we see the found examples as indicators when it comes to the integration of pedagogy in to curricular documents.

Different aspects of dialogicity are illustrated in the classroom examples. The Finnish example demonstrates cumulativity and the Hong Kong example demonstrates purposefulness. Each example 
illustrates one of Alexander's [18] specific principles of dialogic teaching. We acknowledge that many features are interwoven into these examples; however, the interpretations and analyses highlight the different curricular emphases.

The episode from the Finnish lower secondary classroom demonstrates how a teacher can collect student observations to set up the next stage of inquiry. This is an example of cumulativity, as it uses student ideas as the basis for developing more scientific explanations. The teacher in this example explicitly acknowledges student ideas, thus attaining dialogicity. This is rarely found in Finnish science classrooms [21].

The teacher in Hong Kong demonstrates the purposeful use of different interactional and instructional approaches, such as argument-driven inquiry (ADI) [52]. First, the characteristics of the task are discussed and the students' interest in the problem at hand is raised, which is congruent with the first phase of the ADI model and brings strategic purposefulness to the classroom interaction. There can be, however, a thin line between authoritative and dialogic approaches [39], which is realized here, as the purposefulness partly hinders the authentic dialogism. In other words, although the questions open up space for students' authentic wonderment questions and collective idea sharing, the teacher's provocative and almost directing follow-ups signal the goal-oriented nature of the interaction. In a way, the teacher exploits and challenges the students' ideas as a starting point their inquiries.

In addition to dialogic features presented we think that supportivity, as obvious as it may seem, plays an essential role in breaking down the prevailing authoritative norms of interaction [48]. It is through supportivity that teachers can go beyond right and wrong and practice student-centeredness and dialogicity. Giving weight to these softer values could significantly improve student motivation in the long term [13], as students become aware that their efforts are being truly acknowledged as a part of creating classroom science. Nevertheless, supportiveness is not explicitly discussed in the two curricula examined. Although this is partly understandable, we think the explicitness could finally drive changes in teacher education programs, local curricula, text books etc. The lack of supportiveness is especially worrying, as teacher supportiveness is an essential part of student-centeredness: it provides a means for bringing dialogicity and formative assessment into the classroom [54]. Studies have found that teacher supportiveness facilitates students' disclosure of their thinking [55] (p. 552), mediating the ownership of scientific knowledge.

\section{Implications, Limitations and Future Research}

The absence or presence of characteristics of dialogicity in curriculum documents cannot be causally linked to the absence or presence of those characteristics in classroom interactions. Furthermore we couldn't provide illustrative examples of all the principles in both curricula and interactions in this manuscript (see [48] for more classroom examples).

Although it may seem that national policy statements are not the best sources for studies of pedagogy, it should be asked what policy statements are for if not to influence practice. As we cannot confirm teacher intentions here, we propose that the classroom examples represent features of dialogicity that are attainable and explicitly illustrate the interplay between curricula and classroom interaction. This fusion should take place at the levels of principle, strategy and indicator [18].

As discussed, curricular policies may not manifest in classrooms due to the poor communication between curriculum developers and teachers $[25,56]$. There are some indications that involving municipalities, schools and teachers in local curricula work has bridged this gap in Finland [57].

Currently, curricular documents provide some suggestions for instructional strategies, but more pedagogical aspects should also be included. Despite the doubts about how curricular documents can be implemented [25], some studies have reported that curricular derivatives (e.g., school textbooks reflecting curricular guidelines) can encourage implementation [16]. Of course, in addition to curricula and textbooks, student-centeredness should be covered in teacher education [42], often reflecting current trends. There is evidence that even reform-prepared novice teachers feel they are not prepared 
to face classroom realities [58]. Experienced teachers, who tend to teach in the way they have become accustomed, should also be encouraged to update their education to create more reform-oriented schools [59].

Conflicts of Interest: The authors declare no conflict of interest.

\section{Appendix A}

Table A1. Overview of the data set and curricular resources.

\begin{tabular}{|c|c|c|}
\hline Data & Finland & Hong Kong \\
\hline Curriculum & $\begin{array}{l}\text { Finnish National Core Curriculum } 2004 \text { \& } 2014 \\
\text { (Grades 7-9) } \\
\text { (Part III: Chapter 9-Physics) } \\
\text { 2004 Retrieved from } \\
\text { http://www.oph.fi/download/47672_core_ } \\
\text { curricula_basic_education_3.pdf } \\
\text { 2014 Retrieved from (in Finnish) } \\
\text { http://www.oph.fi/download/163777_ } \\
\text { perusopetuksen_opetussuunnitelman_- } \\
\text { perusteet_2014.pdf }\end{array}$ & $\begin{array}{l}\text { Hong Kong Science Curriculum } 1998 \text { \& } 2016 \\
\text { (Grades 7-9) } \\
1998 \text { Retrieved from http://cd1.edb.hkedcity. } \\
\text { net/cd/science/is/sci_syllabus_S1to3_e.pdf } \\
\text { 2016 Retrieved from } \\
\text { http://www.edb.gov.hk/attachment/en/ } \\
\text { curriculum-development/kla/science-edu/ } \\
\text { Science_curriculum_framework_20160831. } \\
\text { pdf }\end{array}$ \\
\hline Initial video data & 25 double lessons ( 25 science teachers) & 16 lessons ( 1 teacher) \\
\hline $\begin{array}{l}\text { Initial project context in } \\
\text { which the data was collected }\end{array}$ & $\begin{array}{l}\text { QuIP (Quality of Instruction in Physics) project } \\
\text { (e.g., Author et al., 2014) }\end{array}$ & $\begin{array}{l}\text { Report on exemplary science teaching } \\
\text { (Wong et al., 2006) }\end{array}$ \\
\hline Selected case data & Teacher Paul (experienced) & Teacher Mark (experienced) \\
\hline Students in case study data & Lower secondary/9th grade (age 14-15) & Junior secondary (age 12) \\
\hline Topic in case study data & Physics/Electrical power and energy & Physics/Density \\
\hline
\end{tabular}

\section{References}

1. Finnish National Board of Education (FNBE). Finnish National Core Curriculum for Basic Education; Valtion Painatuskeskus: Helsinki, Finland, 2004.

2. Finnish National Board of Education (FNBE). Perusopetuksen Opetussuunnitelman Perusteet 2014 [Finnish Core Curriculum for Basic Education 2014]; Valtion Painatuskeskus: Helsinki, Finland, 2016.

3. National Research Council. A Framework for K-12 Science Education: Practices, Crosscutting Concepts, and Core Ideas; National Academies Press: Washington, DC, USA, 2012.

4. Peters, E.E. Shifting to a student-centered science classroom: An exploration of teacher and student changes in perceptions and practices. J. Sci. Teach. Educ. 2010, 21, 329-349. [CrossRef]

5. Littleton, K.; Howe, C. (Eds.) Educational Dialogues: Understanding and Promoting Productive Interaction; Routledge: London, UK, 2009.

6. Mercer, N. Sociocultural discourse analysis: Analysing classroom talk as a social mode of thinking. J. Appl. Linguist. 2004, 1, 137-168. [CrossRef]

7. Bakhtin, M. Speech Genres and Other Late Essays; University of Texas Press: Austin, TX, USA, 1986.

8. Matusov, E. Authorial teaching and learning. In Bakhtinian Pedagogy: Opportunities and Challenges for Research, Policy and Practice in Education across the Globe; White, E.J., Peters, M., Eds.; Peter Lang Publishers: New York, NY, USA, 2011; pp. 21-46.

9. Moate, J. Reconceptualising the Role of Talk in CLIL. Appl. J. Appl. Lang. Stud. 2011, 5, 17-35.

10. Mortimer, E.F.; Scott, P. Meaning Making in Science Classrooms; Open University Press: Buckingham, UK, 2003.

11. Teo, P. Exploring the dialogic space in teaching: A study of teacher talk in the pre-university classroom in Singapore. Teach. Teach. Educ. 2016, 56, 47-60. [CrossRef]

12. Lyons, T. Different countries, same science classes: Students' experiences of school science in their own words. Int. J. Sci. Educ. 2006, 28, 591-613. [CrossRef]

13. Kiemer, K.; Gröschner, A.; Pehmer, A.-K.; Seidel, T. Effects of a classroom discourse intervention on teachers' practice and students' motivation to learn mathematics and science. Learn. Instr. 2015, 35, 94-103. [CrossRef]

14. Cuban, L. Curriculum stability and change. In Handbook of Research on Curriculum: A Project of the American Educational Research Association; Jackson, P.W., Ed.; Macmillan: New York, NY, USA, 1992; pp. $216-247$. 
15. Franklin, B.M. Review essay: The state of curriculum history. Hist. Educ. 1999, 28, 459-476. [CrossRef]

16. Penuel, W.R.; Phillips, R.A.; Harris, C.J. Analyzing curriculum implementation from integrity and actor-oriented perspectives. J. Curric. Stud. 2014, 46, 751-777. [CrossRef]

17. Voogt, J.; Roblin, N.P. A comparative analysis of international frameworks for 21st century competences: Implications for national curriculum policies. J. Curric. Stud. 2012, 44, 299-321. [CrossRef]

18. Alexander, R. Towards Dialogic Teaching, 3rd ed.; Dialogos: York, UK, 2006.

19. Sedova, K.; Sedlacek, M.; Svaricek, R. Teacher professional development as a means of transforming student classroom talk. Teach. Teach. Educ. 2016, 57, 14-25. [CrossRef]

20. Lefstein, A.; Snell, J. Better than Best Practice: developing teaching and learning through dialogue; Routledge: London, UK, 2014.

21. Lehesvuori, S.; Viiri, J.; Rasku-Puttonen, H.; Moate, J.; Helaakoski, J. Visualizing communication structures in science classrooms: Tracing cumulativity in teacher-led whole class discussions. J. Res. Sci. Teach. 2013, 50, 912-939. [CrossRef]

22. Fuchs, L.S.; Deno, S.L. Must instructionally useful performance assessment be based in the curriculum? Except. Child. 1994, 61, 15-24. [CrossRef]

23. Howell, K.W.; Evans, D.G. Must instructionally useful performance assessment be based in the curriculum? Comment. Except. Child. 1995, 61, 394-396. [CrossRef]

24. Hannafin, M.J.; Hannafin, K.M. Cognition and student-centered, web-based learning: Issues and implications for research and theory. In Learning and Instruction in the Digital Age; Spector, J.M., Ifenthaler, D., Isaias, P., Sampson, K., Eds.; Springer Science Business Media: New York, NY, USA, 2010; pp. 11-23.

25. Fernandez, T.; Ritchie, G.; Barker, M. A sociocultural analysis of mandated curriculum change: The implementation of a new senior physics curriculum in New Zealand schools. J. Curric. Stud. 2008, 40, 187-213. [CrossRef]

26. Curriculum Development Council (CDC). Science (Secondary 1-3) Curriculum Framework Supplement to the Science Education KLA Curriculum Guide (P1-S6); Government Printer: Hong Kong, China, 2016.

27. Curriculum Development Council (CDC). Syllabuses for Secondary Schools: Science Secondary 1-3; Government Printer: Hong Kong, China, 1998.

28. Oliveira, A.W. Developing Elementary Teachers' Understandings of Hedges and Personal Pronouns in Inquiry-Based Science Classroom Discourse. J. Res. Sci. Educ. 2009, 8, 247-269. [CrossRef]

29. National Research Council. National Science Education Standards; National Academies Press: Washington, DC, USA, 2000.

30. Wells, G. Dialogic Inquiry: Towards a Sociocultural Practice and Theory of Education; Cambridge University Press: Cambridge, UK, 1999.

31. Sadeh, I.; Zion, M. The development of dynamic inquiry performances within an open inquiry setting: A comparison to guided inquiry setting. J. Res. Sci. Teach. 2009, 40, 1137-1160.

32. Scott, P.; Ametller, J. Teaching science in a meaningful way: Striking a balance between 'opening up' and 'closing down' classroom talk. School Sci. Rev. 2007, 88, 77-83.

33. Thompson, P. Both dialogic and dialectic: 'Translation at the crossroads'. Learn. Cult. Soc. Interact. 2012, 1, 90-101. [CrossRef]

34. Wahlström, N. Learning to communicate or communicating to learn? A conceptual discussion on communication, meaning, and knowledge. J. Curric. Stud. 2010, 42, 431-449. [CrossRef]

35. Lemke, J.L. Talking Science: Language, Learning and Values; Ablex Publishing Company: Norwood, MA, USA, 1990.

36. Sinclair, J.; Coulthard, R.M. Towards an analysis of discourse; Oxford University Press: Oxford, UK, 1975.

37. Chin, C. Teacher questioning in science classrooms: Approaches that stimulate productive thinking. J. Res. Sci. Teach. 2007, 44, 815-843. [CrossRef]

38. Cullen, R. Supportive teacher talk: The importance of the F-move. ELT J. 2002, 56, 117-126. [CrossRef]

39. Scott, P.H.; Mortimer, E.F.; Aguiar, O.G. The tension between authoritative and dialogic discourse: A fundamental characteristic of meaning making interactions in high school science lessons. Sci. Educ. 2006, 90, 605-631. [CrossRef]

40. Rojas-Drummond, S.; Mercer, N.; Dabrowski, E. Collaboration, scaffolding and the promotion of problem solving strategies in Mexican pre-schoolers. Eur. J. Psych. Ed. 2001, XVI, 179-196. [CrossRef] 
41. Sedova, K.; Salamounova, Z.; Svaricek, R. Troubles with dialogic teaching. Learn. Cult. Soc. Interact. 2014, 3, 274-285. [CrossRef]

42. Lehesvuori, S.; Viiri, J.; Rasku-Puttonen, H. Introducing Dialogic Teaching to Science Student Teachers. J. Sci. Teach. Educ. 2011, 22, 705-727. [CrossRef]

43. Wong, S.L.; Young, B.H.W.; Chen, M.W.; Lam, K.L.; Hodson, D. Setting the stage for developing preservice teachers' conceptions of good science teaching: The role of classroom videos. Int. J. Sci. Educ. 2006, 28, 1-24. [CrossRef]

44. Lavrenteva, E.; Orland-Barak, L. The treatment of culture in the foreign language curriculum: An analysis of national curriculum documents. J. Curric. Stud. 2015, 47, 653-684. [CrossRef]

45. Ben-Peretz, M. Analysis and Comparison of Some High School Biology Curricula in Israel: Theoretical and Practical Considerations in the Process of Curriculum Development; Hebrew University: Jerusalem, Israel, 1977.

46. Dick, W.; Carey, L.; Carey, J. The Systematic Design of Instruction, 5th ed.; Allyn \& Bacon: Boston, MA, USA, 2001.

47. Mercer, N. Words and Minds: How We Use Language to Think Together; Routledge: London, UK, 2000.

48. Lehesvuori, S.; Ramnarain, U.; Viiri, J. Challenging Transmission Modes of Teaching in Science Classrooms: Enhancing Learner-Centredness through Dialogicity. Res. Sci. Educ. 2017. Available online: https://doi.org/ 10.1007/s11165-016-9598-7 (accessed on 20 August 2017). [CrossRef]

49. Cohen, L.; Manion, L.; Morrison, K. Research Methods in Education, 6th ed.; Routledge Falmer: London, UK, 2007.

50. Osborne, J.; Erduran, S.; Simon, S. Enhancing the quality of argumentation in school science. J. Res. Sci. Teach. 2004, 41, 994-1020. [CrossRef]

51. Berland, K.B.; Hammer, D. Framing for scientific argumentation. J. Res. Sci. Teach. 2012, 49, 68-94. [CrossRef]

52. Walker, J.P.; Sampson, V. Learning to argue and arguing to learn: Argument-driven inquiry as a way to help undergraduate chemistry students learn how to construct arguments and engage in argumentation during a laboratory course. J. Res. Sci. Teach. 2013, 50, 561-596. [CrossRef]

53. Osborne, J.; Simon, S.; Christodoulou, A.; Howell-Richardson, C.; Richardson, K. Learning to argue: A study of four schools and their attempt to develop the use of argumentation as a common instructional practice and its impact on students. J. Res. Sci. Teach. 2013, 50, 315-347. [CrossRef]

54. Ruiz-Primo, M.A. Informal formative assessment: The role of instructional dialogues in assessing students' learning. Stud. Educ. Eval. 2011, 37, 15-24. [CrossRef]

55. Bell, B.; Cowie, B. The characteristics of formative assessment in science education. Sci. Educ. 2001, 85, 536-553. [CrossRef]

56. Salonen-Hakomäki, S.-M.; Soini, T.; Pietarinen, J.; Pyhältö, K. The way ahead for Finnish comprehensive school? Examining state-level school administrators' theory of change. J. Curric. Stud. 2016, 48, 671-691. [CrossRef]

57. Mølstad, C.E. State-based curriculum-making: Approaches to local curriculum work in Norway and Finland. J. Curric. Stud. 2015, 47, 441-461. [CrossRef]

58. Stuart, C.; Thurlow, D. Making it their own: Preservice teachers' experiences, beliefs, and classroom practices. J. Teach. Educ. 2000, 51, 113-121. [CrossRef]

59. Abell, S.K. (Ed.) Science Teacher Education: An International Perspective; Kluwer Academic Publishers: Dordrecht, The Netherlands, 2000.

(C) 2017 by the authors. Licensee MDPI, Basel, Switzerland. This article is an open access article distributed under the terms and conditions of the Creative Commons Attribution (CC BY) license (http:/ / creativecommons.org/licenses/by/4.0/). 